\title{
Evaluation of agro-based waste substrates for micropropagule formation in biocontrol fungi, Trichoderma asperellum and $T$. harzianum
}

\author{
Hasan ZAE ${ }^{1,2}$, Mohd Zainudin NAI ${ }^{*}$, Aris $\mathrm{A}^{1}$, Ibrahim $\mathrm{MH}^{1}$ and Yusof $\mathrm{MT}^{3}$ \\ ${ }^{1}$ Department of Biology, Faculty of Science, Universiti Putra Malaysia, 43400 Serdang Selangor, Malaysia \\ ${ }^{2}$ Department of Botany, Faculty of Science, Omar Al Mukhtar University, Al Bayda, Libya \\ ${ }^{3}$ Department of Microbiology, Faculty of Biotechnology and Biomolecular Sciences, Universiti Putra Malaysia, 43400 \\ Serdang, Selangor, Malaysia
}

Hasan ZAE, Mohd Zainudin NAI, Aris A, Ibrahim MH, Yusof MT 2020 - Evaluation of agrobased waste substrates on micropropagule of Trichoderma asperellum and Trichoderma harzianum. Studies in Fungi 5(1), 94-102, Doi 10.5943/sif/5/1/9

\begin{abstract}
Trichoderma species have shown efficiency on biocontrol of phytopathogens. For commercial application, it must be propagated in mass scale using a cost-effective method. As an alternative way to effectively deliver biocontrol fungi inoculum to the field; seven agro-based wastes including rice bran, biochar, empty fruit bunches, coconut fibre, compost, topsoil and mixed soil were used in this study for evaluating mass multiplication of Trichoderma species. Based on the evaluation of colony-forming units (cfu) among the agro-based waste media used, coconut fibre is the most suitable in promoting the sporulation of Trichoderma asperellum and T. harzianum. Trichoderma asperellum C1667 showed the higher micropropagule count through incubation period compared to $T$. harzianum C1675. After 120 days on the agro-based waste media, $T$. asperellum $\mathrm{C} 1667$ and $T$. harzianum $\mathrm{C} 1675$ produced the highest $\left(7.717 \times 10^{5} \mathrm{cfu} / \mathrm{g}\right.$ and $6.836 \pm 13.79 \times 10^{5} \mathrm{cfu} / \mathrm{g}$ ) coconut fibres, respectively. Meanwhile, the mixed soil appeared with the lowest cfu. Coconut fibres were shown as a great biocomposting medium for both Trichoderma species. Findings of the present study are valuable for disease management using agro-based wastes as a cost-effective medium for biocontrol agents like Trichoderma species.
\end{abstract}

Key words - Biocontrol agent - mass multiplication - shelf life

\section{Introduction}

The success of bio-controlling soil-borne plant pathogens depends mainly on the ability of introduced microorganisms. One of the mechanisms is to competitively colonise the rhizosphere of host plant, which can influence the availability of nutrients from the substrate or carrier medium through the biocontrol agent applied (Köhl et al. 2019). Several techniques have been employed such as direct application using single strain, mixture of Trichoderma strains or combined with thiophanate-methyl for the multiplication of Trichoderma species (Stewart \& Hill 2014, Marra et al. 2017, Abd-El-Khair et al. 2019). There are studies that introduced Trichoderma species to the soil as mycelia preparations growing on agricultural or industrial waste considered as economical media such as compost (Leandro et al. 2007), rice bran (Cavalcante et al. 2008), coconut coir (Kumar \& Palakshappa 2009), empty fruit bunch (Siddiquee et al. 2017) and biochar (Graber et al. 2014, Muter \& Olga 2017). Although there have been several studies conducted on the use of 
Trichoderma spp. as a biocontrol agent in controlling some forms of plant pathogens (Bae et al. 2011, Mandal et al. 2016, Nosir 2016), there are limited studies investigating how Trichoderma survive and proliferate in the soil.

Trichoderma species grow on different substrates of carbon and nitrogen through the massive secretion of complex mixtures of specific extracellular enzymes (Vinale et al. 2014, Siddiquee et al. 2017, Sala et al. 2019) and able to enhance plant growth performance (Pandya \& Saraf 2010). Therefore, the successful biocontrol of pathogen by Trichoderma isolates depends on their ability to survive and remain active in the soil for a long period. In this study, seven media were selected as they are inexpensive sources, which were inoculated with Trichoderma to obtain higher levels of survival and proliferation to reduce disease. In this context, due to the importance of Trichoderma isolates' survival in the environment, the objectives of this study are to distinguish the most suitable agro-based wastes as a natural medium for efficient micropropagule production of Trichoderma asperellum and $T$. harzianum based on colony forming units (cfus) counts and to determine the longest survival duration of Trichoderma with the highest productivity.

\section{Materials \& Methods}

\section{Trichoderma culture}

Trichoderma asperellum and T. harzianum were chosen in this study because both isolates showed a very high antagonistic activity based on inhibition of radial growth (PIRG) as reported by Zainap et al. (2018). The origin and PIRG are tabulated in Table 1 based on dual culture assay against Fusarium oxysporum f. sp. lycopersici B713T, a causal agent of fruit rot and Fusarium wilt diseases of tomato. Both isolates were cultured on potatoes dextrose agar (PDA) and incubated at $\left(28 \pm 2^{\circ} \mathrm{C}\right)$ for 7 days. Fungal conidia were harvested from 7 -day culture. The concentration of conidia was adjusted to $1 \times 10^{6}$ conidia/ml using a haemocytometer.

Table 1 Origin and inhibitory activity of the three best antagonistic Trichoderma isolates on mycelial growth of F. oxysporum f. sp. lycopersici B713T, a causal agent of Fusarium wilt disease of tomato in dual culture (Zainap et al. 2018)

\begin{tabular}{lcccc}
\hline Isolate no. & Locality & Species & PIRG \pm SD & aAntagonistic activity \\
\hline C1667 & Maran, Pahang & T. asperellum & $80.27 \pm 0.54$ & very high \\
C1675 & Maran, Pahang & T. harzianum & $78.45 \pm 0.88$ & very high \\
a $>$ 75 PIRG $=$ very high antagonist activity, $61-75$ PIRG & $=$ high \\
antagonist activity, & $<$ a & a PIRG = low antagonist activity, & 51-60 PIRG = moderate
\end{tabular}

\section{Preparation of media and fungal inoculation}

Agro-based wastes used in this study were mixed soil, topsoil, rice-bran, compost, coconut fibre, oil palm empty fruit bunch and biochar (Fig. 1). All the agro-based wastes were obtained from different suppliers due to the limited resources. Topsoil, mixed soil, rice-bran, compost and coconut fibre were purchased from D Syira Enterprise, Selangor, Malaysia. Oil palm empty fruit bunch (EFB) was obtained from Felda Jengka 21 Palm Oil Factory, Pahang, Malaysia while biochar was purchased from YMWOO Corporation Sdn Bhd, Kuala Lumpur, Malaysia. Each medium (200 g) was put in a polybag and inoculated with $1 \times 10^{6}$ conidia/ml, five replicates per treatment. The inoculated media were incubated at plant house condition. Sangle et al. (2004) reported that $50 \%$ of moisture is essential for sporulation; therefore, the media were adjusted to $50 \%$ moisture daily using distilled water where sufficient water was added to adjust the moisture intensity in all media and incubated in a polybag for 120 days. The experiments were repeated for three times.

\section{Measurement of colony-forming unit (cfu) of Trichoderma}

Colony forming unit (cfu) of Trichoderma isolates that survived in each medium was counted using soil dilution isolation technique. The cfu data were recorded at day 15, 30, 45, 60, 75, 90, 105 
and 120 after inoculation.

Evaluation of cfu of Trichoderma was conducted by mixing $10 \mathrm{~g}$ of the inoculated medium sample with $100 \mathrm{ml}$ sterile distilled water followed by agitation in an environmental orbital shaker at $100 \mathrm{rpm}$ for 10 minutes. The serial dilutions at $10^{-3}$ were used for cfu estimation. $1 \mathrm{ml}$ of soil solution was pipetted out and seeded into each Petri dish followed by pouring $9 \mathrm{ml}$ of sterilised Trichoderma selective medium (TSM) (Elad et al. 1981). The culture plates were incubated for 4 days at room temperature, $28 \pm 2^{\circ} \mathrm{C}$. The plates were examined daily and the cfu of Trichoderma was calculated.
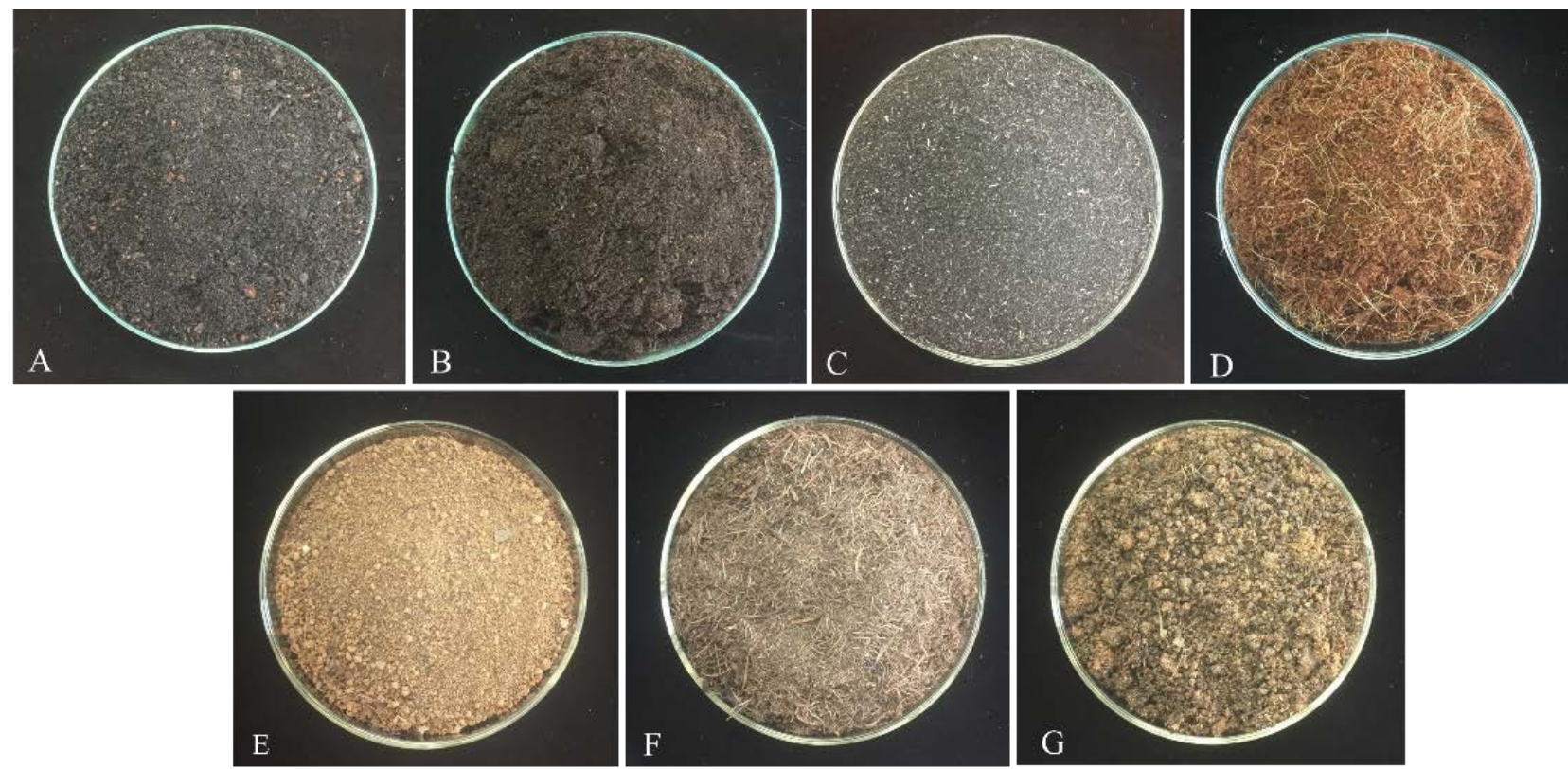

Fig. 1 - Seven media used in this study. A Biochar. B Compost. C Rice-bran. D Coconut fibre. E Topsoil. F Oil palm empty fruit bunch. G Mixed soil.

\section{Data analysis}

The cfu of Trichoderma was recorded and analysed by One-way ANOVA followed by Least Significant Difference (LSD) in which all data were employed in SPSS software v.22.0 (Armonk, NY: IBM Corp).

\section{Results}

The presented data revealed that the population of Trichoderma isolated from the inoculated agro-based wastes media significantly differed from mixed soil at 15, 30, 45, 60, 75, 90, 105 and 120 days of inoculation. The population of inoculated-Trichoderma was varied according to the isolates of Trichoderma as tabulated in Table 2. Based on the cfu evaluation among the media, coconut fibre was the most suitable in promoting the sporulation of Trichoderma. The finding showed $T$. asperellum isolate C1667 gave the greater population in all time periods compared to $T$. harzianum isolate C1675 as shown in Figs 2-3.

After 15 days of inoculation, all media recorded a very high concentration of cfu. These include topsoil, mixed soil, rice bran, compost, coconut fibre, oil palm empty fruit bunch and biochar. Media inoculated with T. asperellum C1667 at different periods at 60 days after inoculation gave a greater population density than that of other ages and in 120 days old. They recorded the least population in all media by $0.8 \times 10^{3}, 0.2 \times 10^{3}, 77 \times 10^{3}, 94 \times 10^{3}, 7.717 \times 10^{5}$, $5.984 \times 10^{5}, 0.37 \times 10^{5} \mathrm{cfu} / \mathrm{g}$ for top soil, mixed soil, rice bran, compost, coconut fibre, oil palm empty fruit bunch and biochar, respectively. As for inoculation, the media by T. harzianum C1675 recorded the highest cfu at day 60 after inoculation and continued to decline until at the end of experiment (Fig. 4). 
Table 2 Colony forming unit (cfu) of T. asperellum C1667 and T. harzianum C1675 in seven types of media inoculated with fungal conidia.

\begin{tabular}{|c|c|c|c|c|c|c|c|}
\hline \multirow{2}{*}{$\begin{array}{c}\text { Days of } \\
\text { inoculation }\end{array}$} & \multicolumn{7}{|c|}{ T. asperellum C1667 $\left(*\right.$ mean $\left.x 10^{3} * * \mathrm{cfu} / \mathrm{g}\right)$} \\
\hline & Topsoil & Mixed soil & Rice bran & Compost & Coconut fibre & EFB & Biochar \\
\hline 15 & $95.80 \pm 11.19^{\mathrm{c}}$ & $68.90 \pm 6.29^{\mathrm{d}}$ & $246.00 \pm 16.87^{b}$ & $133.60 \pm 14.79^{c}$ & $996.90 \pm 13.12^{\mathrm{a}}$ & $1041.50 \pm 16.30^{\mathrm{a}}$ & $234.80 \pm 15.83^{\mathrm{b}}$ \\
\hline 30 & $85.20 \pm 8.43^{\mathrm{d}}$ & $63.50 \pm 6.69^{d}$ & $114.30 \pm 12.02^{\mathrm{c}}$ & $125.90 \pm 10.43^{c}$ & $899.30 \pm 15.18^{\mathrm{a}}$ & $906.50 \pm 10.46^{\mathrm{a}}$ & $312.10 \pm 10.86^{b}$ \\
\hline 45 & $155.50 \pm 12.72^{\mathrm{d}}$ & $63.90 \pm 5.05^{\mathrm{e}}$ & $94.70 \pm 12.80^{\mathrm{e}}$ & $42.20 \pm 6.75^{\mathrm{e}}$ & $1043.10 \pm 13.37^{\mathrm{a}}$ & $991.30 \pm 11.31^{\mathrm{b}}$ & $324.60 \pm 11.79^{c}$ \\
\hline 60 & $117.00 \pm 1.29^{c}$ & $31.00 \pm 4.44^{\mathrm{d}}$ & $117.40 \pm 2.44^{\mathrm{c}}$ & $141.70 \pm 16.24^{c}$ & $1064.30 \pm 14.06^{\mathrm{a}}$ & $1099.40 \pm 14.05^{\mathrm{a}}$ & $345.90 \pm 12.63^{b}$ \\
\hline 75 & $82.10 \pm 2.65^{\mathrm{d}}$ & $73.60 \pm 7.04^{\mathrm{d}}$ & $423.80 \pm 9.44^{\mathrm{b}}$ & $116.50 \pm 9.04^{\mathrm{c}}$ & $1061.90 \pm 11.11^{\mathrm{a}}$ & $1081.70 \pm 13.38^{\mathrm{a}}$ & $260.10 \pm 12.37^{c}$ \\
\hline 90 & $36.70 \pm 6.00^{\mathrm{e}}$ & $0.90 \pm 0.17^{\mathrm{e}}$ & $436.00 \pm 10.29^{c}$ & $273.60 \pm 16.75^{\mathrm{d}}$ & $1010.00 \pm 15.88^{\mathrm{a}}$ & $807.90 \pm 15.02^{b}$ & $296.60 \pm 14.61^{\mathrm{d}}$ \\
\hline 105 & $21.50 \pm 1.43^{\mathrm{e}}$ & $0.50 \pm 0.16^{\mathrm{e}}$ & $140.20 \pm 11.32^{\mathrm{d}}$ & $242.00 \pm 11.21^{\mathrm{c}}$ & $834.50 \pm 9.40^{\mathrm{a}}$ & $657.10 \pm 11.49^{b}$ & $25.80 \pm 3.90^{\mathrm{e}}$ \\
\hline 120 & $0.80 \pm 0.35^{\mathrm{e}}$ & $0.20 \pm 0.13^{\mathrm{e}}$ & $77.00 \pm 4.55^{\mathrm{d}}$ & $94.00 \pm 6.56^{c}$ & $771.70 \pm 13.58^{\mathrm{a}}$ & $598.40 \pm 13.87^{\mathrm{b}}$ & $37.00 \pm 4.53^{\mathrm{e}}$ \\
\hline \multirow{2}{*}{$\begin{array}{c}\text { Days of } \\
\text { inoculation }\end{array}$} & \multicolumn{7}{|c|}{ T. harzianum C1675 (*mean x10 $\left.{ }^{3} * * \mathrm{cfu} / \mathrm{g}\right)$} \\
\hline & Top soil & Mixed soil & Rice bran & Compost & Coconut fibre & EFB & Biochar \\
\hline 15 & $86.40 \pm 7.23^{\mathrm{d}}$ & $76.90 \pm 5.64^{\mathrm{d}}$ & $204.80 \pm 16.94^{c}$ & $210.80 \pm 14.58^{c}$ & $950.70 \pm 13.30^{\mathrm{b}}$ & $1018.10 \pm 15.52^{\mathrm{a}}$ & $158.00 \pm 9.35^{c}$ \\
\hline 30 & $95.60 \pm 11.04^{\mathrm{c}}$ & $59.20 \pm 9.65^{\mathrm{d}}$ & $204.10 \pm 15.63^{b}$ & $119.90 \pm 16.96^{c}$ & $860.50 \pm 13.12^{\mathrm{a}}$ & $956.40 \pm 12.75^{a}$ & $325.10 \pm 12.35^{b}$ \\
\hline 45 & $110.20 \pm 11.72^{\mathrm{c}}$ & $48.10 \pm 9.50^{\mathrm{d}}$ & $99.10 \pm 12.97^{c}$ & $129.30 \pm 14.40^{c}$ & $906.30 \pm 13.95^{\mathrm{a}}$ & $961.80 \pm 13.51^{\mathrm{a}}$ & $367.60 \pm 14.59^{b}$ \\
\hline 60 & $127.20 \pm 8.70^{\mathrm{e}}$ & $28.10 \pm 4.15^{\mathrm{f}}$ & $382.00 \pm 9.37^{\mathrm{d}}$ & $127.40 \pm 12.73^{e}$ & $913.90 \pm 13.95^{\mathrm{b}}$ & $1071.10 \pm 14.78^{a}$ & $362.00 \pm 8.62^{\mathrm{d}}$ \\
\hline 75 & $91.50 \pm 3.00^{d}$ & $55.20 \pm 1.99^{d}$ & $305.70 \pm 15.95^{c}$ & $60.60 \pm 6.45^{\mathrm{d}}$ & $904.40 \pm 11.64^{b}$ & $1010.10 \pm 9.57^{\mathrm{a}}$ & $305.60 \pm 10.47^{c}$ \\
\hline 90 & $8.20 \pm 0.41^{\mathrm{e}}$ & $0.80 \pm 0.20^{\mathrm{e}}$ & $114.00 \pm 3.25^{\mathrm{d}}$ & $213.20 \pm 12.83^{c}$ & $914.30 \pm 14.37^{\mathrm{a}}$ & $766.10 \pm 11.85^{b}$ & $192.20 \pm 14.69^{c}$ \\
\hline 105 & $4.90 \pm 1.00^{\mathrm{d}}$ & $0.20 \pm 0.13^{\mathrm{d}}$ & $116.90 \pm 3.38^{c}$ & $266.50 \pm 11.20^{c}$ & $806.50 \pm 15.60^{\mathrm{a}}$ & $679.10 \pm 13.84^{\mathrm{b}}$ & $17.40 \pm 1.46^{\mathrm{d}}$ \\
\hline 120 & $0.90 \pm 0.48^{\mathrm{e}}$ & $0.20 \pm 0.13^{\mathrm{e}}$ & $65.60 \pm 4.36^{\mathrm{d}}$ & $104.50 \pm 8.33^{c}$ & $683.60 \pm 13.79^{a}$ & $548.30 \pm 12.92^{\mathrm{b}}$ & $45.20 \pm 3.29^{d}$ \\
\hline
\end{tabular}

* Mean of colony forming unit (cfu) /g soil on Trichoderma selective medium (TSM)

** Value followed by the different letter within a row are significantly different $(\mathrm{p}<0.05)$ according to Duncan's two-way ANOVA

Nevertheless, the high cfu of coconut and oil palm fibre could hold them after four months up to the standard level. From the observation, the isolate can survive for a longer period. Regarding this issue and advantages of organic materials, coconut fibre can be the perfect solution with the use of Trichoderma in the biocontrol of plant disease. The result provided implies that micropropagules from Trichoderma ssp. can be efficiently produced with coconut fibre and oil palm fibre, which are inexpensive and abundant agricultural by-products. It is also significant to state that all the cfu production processes were carried without adding extra nutrients to the production medium.

\section{Discussion}

Coconut fibre is a great medium for micropropagule of Trichoderma, suggesting that this medium can be used as a new way to save and keep fungi for a long period. Asiah et al. (2004) reported that coconut coir dust has higher nutrient contents $\left(\mathrm{P}, \mathrm{K}^{+}, \mathrm{Ca}^{2+}\right.$ and $\left.\mathrm{Mg}^{2+}\right)$ than in empty fruit 
bunches. Trichoderma could produce chlamydospores and maintain long periods of vigorous vegetative growth during use (Fravel 2005). Ali et al. (2012) found a decrease in cfu of $T$. harzianum during the period of incubation than the initial count at the beginning of their experiment.

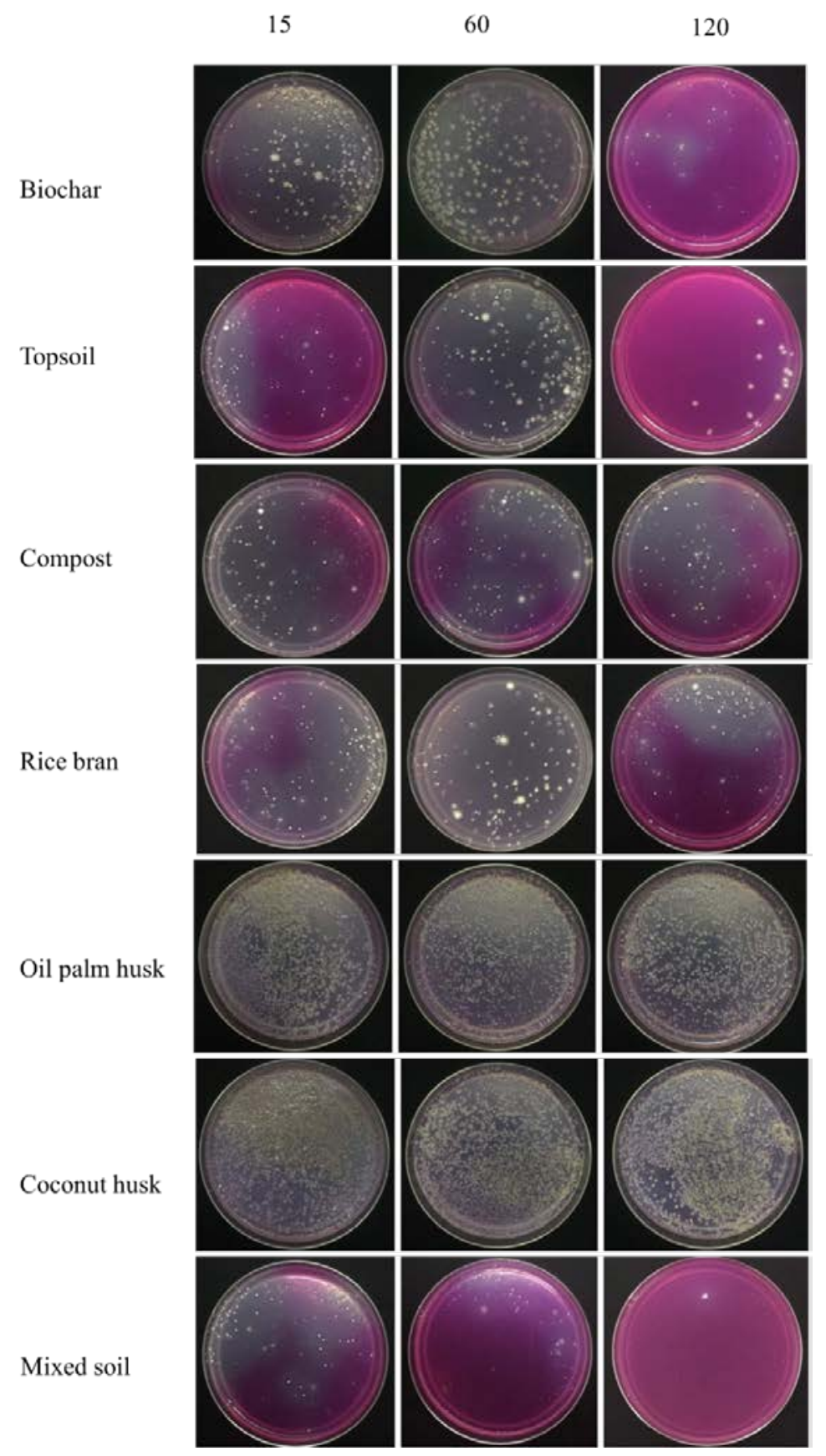

Fig. 2 - Growth of Trichoderma asperellum C1667 at 15, 60 and 120 days after inoculation in different types of media.

Amira et al. (2011) revealed that adding T. virens to oil palm empty fruit bunches and palm oil mill discharge shortened the composting time due to enzymatic activity that was at a greater level. Lewis \& Papavizas (1984) also showed the potential of different Trichoderma sp. collections to develop chlamydospores easily and in abundance in natural soil as well as in parts of organic matter. When fungus was introduced to the soil as conidia, isolates were included as they can aggressively colonise and position themselves in organic matter within the natural environment. The addition of Trichoderma to soil as dry formulation seemed to multiply significantly (Lewis \& 
Papavizas 1984), demonstrating an increase from the original amount of $5 \times 10^{3}$ to a peak of $6-7 \times 10^{6}$ conidia/g of the soil with different organic matter content. Tewari \& Bhanu (2004) carried out solid-state fermentation of $T$. harzianum on various substrates and found that rice straw and wheat straw resulted in high conidial yield of $4.95 \times 10^{8} \mathrm{cfu} / \mathrm{g}$ and $4.86 \times 10^{8} \mathrm{cfu} / \mathrm{g}$, respectively. Media containing paper waste, rice bran and chickpea flour were utilized for mass production of $T$. harzianum and reported a cfu of $11.73 \times 10^{9} \mathrm{cfu} / \mathrm{g}$ following 10 days of incubation (Tewari \& Bhanu 2004). The use of cow dung, beem cake, coir pith, sorghum grains, sawdust and rice bran in mass production of T. harzianum and T. viride improved conidial yield from $23.66 \times 10^{8}$ to $34.00 \times 10^{8}$ and $45.6 \times 10^{8} \mathrm{cfu} / \mathrm{g}$, respectively (Rini \& Sulochana 2006). These studies proved that Trichoderma can be cultured and maintained in various media with different organic matter content. For instance, in many species of Trichoderma, biotic factors particularly $\mathrm{C} / \mathrm{N}$ ratio influenced the formation of conidiospore (Gao et al. 2007).

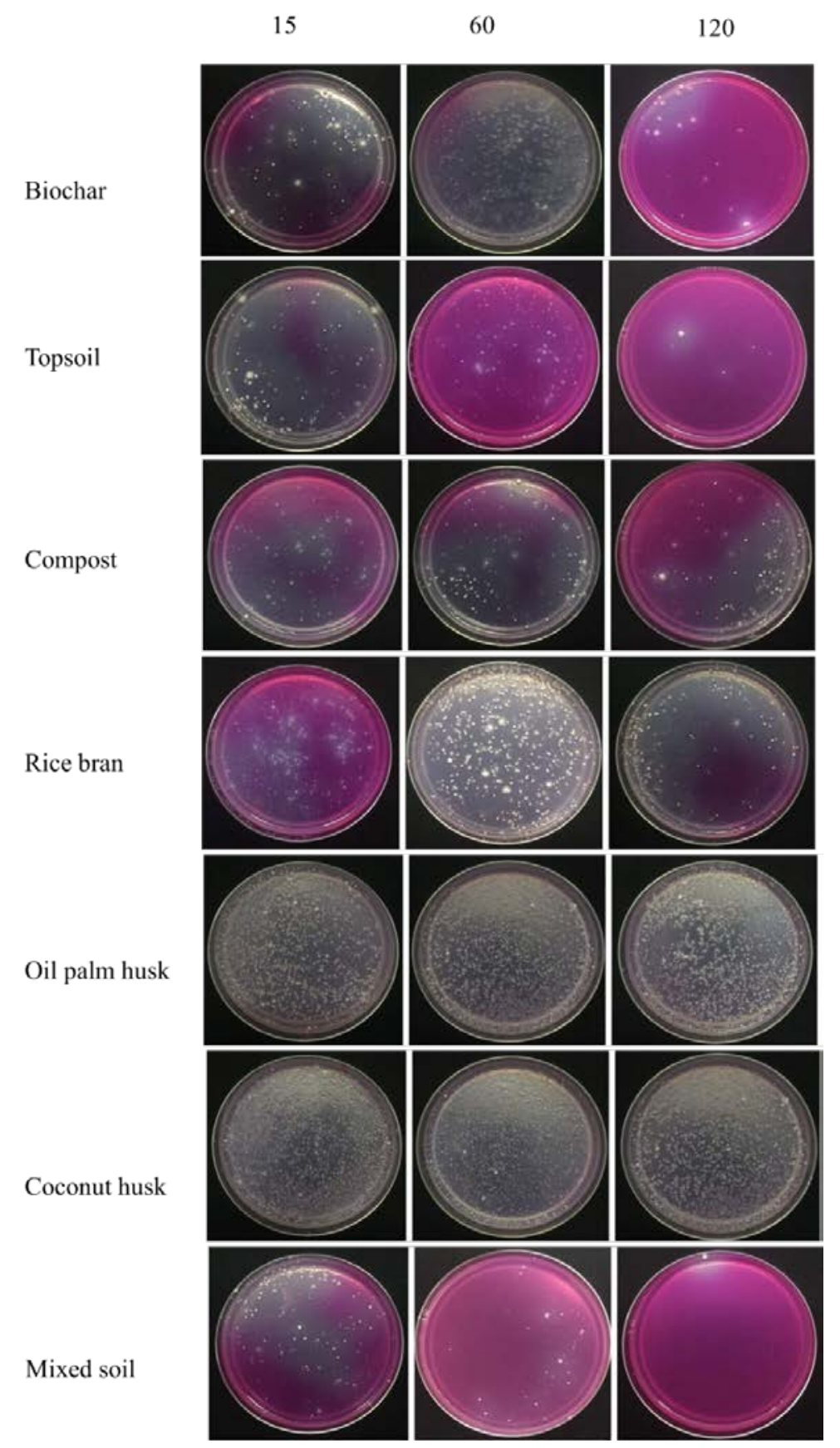

Fig. 3 - Growth of Trichoderma harzianum C1675 at 15, 60 and 120 days after inoculation in different types of media. 

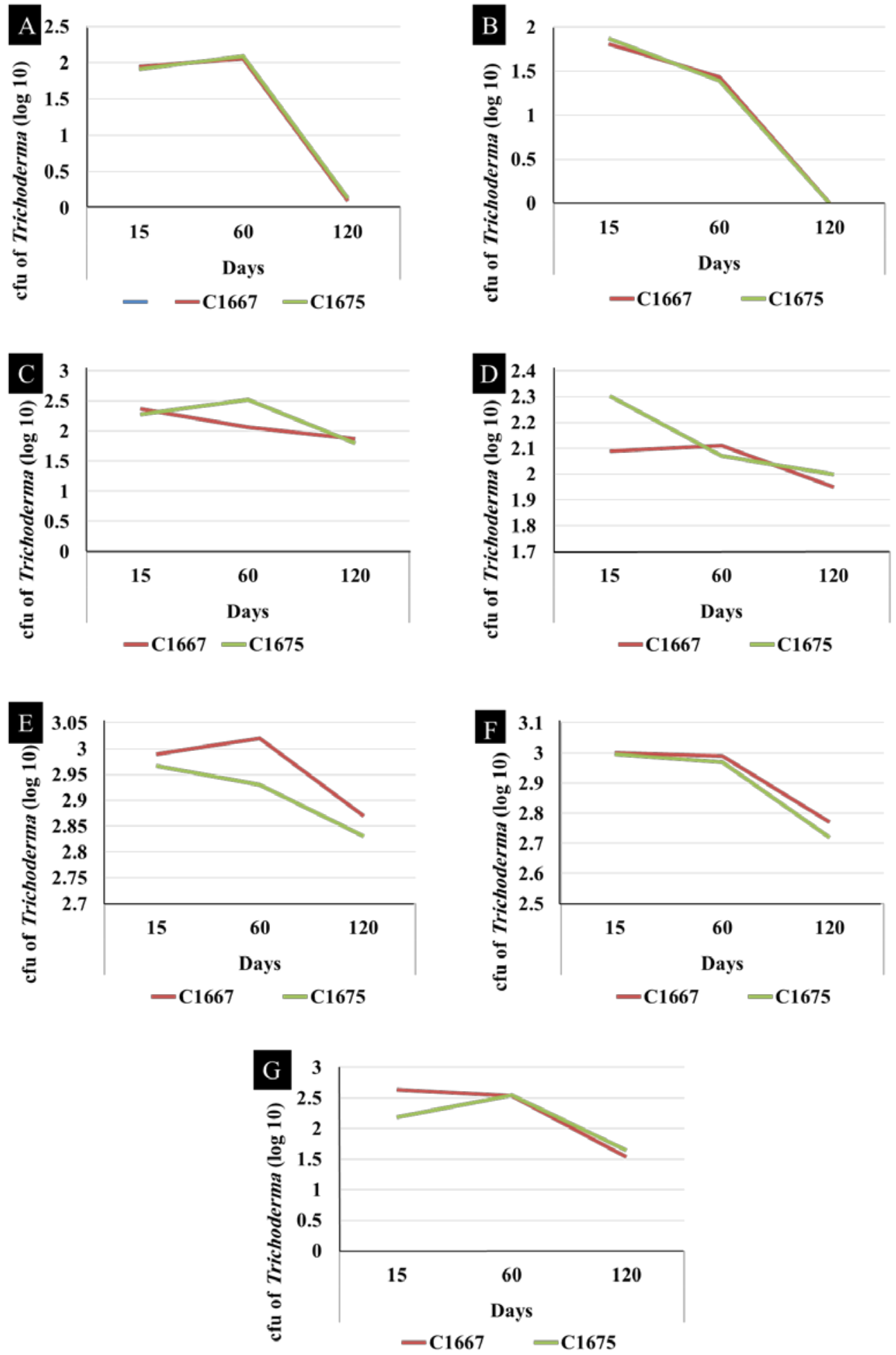

Fig. 4 - Survival of Trichoderma spp. in seven types of media in 15, 60 and 120 days of incubation. Where A) Topsoil B) Mixed soil C) Rice bran D) Compost E) Coconut fibre F) oil palm empty fruit bunch (EFB) and G) Biochar.

The composting of organic wastes with the help of Trichoderma does not only helps in recycling waste literally, but also give good results in the preparation of economic and environmentally friendly organic biofertilisers. Coconut fibre followed by oil palm empty fruit bunch was more favorable as a medium used for the survival and proliferation of the tested fungus. This approach could provide benefits to agriculture crops since it gave the highest biomass and 
number of cfu/g as observed on T. asperellum C1667 and T. harzianum C1675 using cost-effective media in this study.

\section{Acknowledgements}

The authors gratefully acknowledge Mycology lab assistant, Mrs. Nor Hidayah Husain, for her technical assistance and appreciate those who provided valuable and constructive suggestions during the planning and development of this research work. This work was supported by the Putra Grant (IPS), Universiti Putra Malaysia [grant numbers UPM/700-2/1/GP-IPS/2017/9577700].

\section{References}

Abd-El-Khair H, Elshahawy IE, Karima HE. 2019 - Field application of Trichoderma spp. combined with thiophanate-methyl for controlling Fusarium solani and Fusarium oxysporum in dry bean. Bulletin of the National Research Centre 43, 19.

Ali MI, Yasser MM, Mousa AS, Khalek MA. 2012 - Optimization of factors affecting proliferation and flourishment of Trichoderma harzianum in Egyptian soil. Journal of Basic and Applied Mycology 3, 41-48.

Amira RD, Roshanida AR, Rosli MI, Zahrah MSF et al. 2011 - Bioconversion of empty fruit bunches (EFB) and palm oil mill effluent (POME) into compost using Trichoderma virens. African Journal of Biotechnology 10(81), 18775-18780.

Asiah A, MohdRazi I, MohdKhanif Y, Marziah M, Shaharuddin M. 2004 - Physical and chemical properties of coconut coir dust and oil palm empty fruit bunch and the growth of hybrid heat tolerant cauliflower plant. Pertanika Journal of Tropical Agricultural Science 27, 121-133.

Bae H, Roberts DP, Lim HS, Strem MD et al. 2011 - Endophytic Trichoderma isolates from tropical environments delay disease onset and induce resistance against Phytophthora capsici in hot pepper using multiple mechanisms. Molecular Plant-Microbe Interactions, 24, 336351.

Cavalcante RS, Lima HL, Pinto GA, Gava CA, Rodrigues S. 2008 - Effect of moisture on Trichoderma conidia production on corn and wheat bran by solid state fermentation. Food and Bioprocess Technology 1(1), 100-104.

Elad Y, Chet I, Henis Y. 1981 - Biological control of Rhizoctonia solani in strawberry fields by Trichoderma harzianum. Plant and Soil 60(2), 245-254.

Fravel DR. 2005 - Commercialization and implementation of biocontrol. Annual Review of Phytopathology 43, 337-359.

Gao L, Sun MH, Liu XZ, Che YS. 2007 - Effects of carbon concentration and carbon to nitrogen ratio on the growth and sporulation of several biocontrol fungi. Mycological Research 111, 87-92.

Graber ER, Frenkel O, Jaiswal AK, Elad Y. 2014 - How may biochar influence severity of diseases caused by soilborne pathogens? Carbon Management 5(2), 169-183.

Köhl J, Kolnaar R, Ravensberg WJ. 2019 - Mode of action of microbial biological control agents against plant diseases: relevance beyond efficacy. Frontiers in Plant Science 10, 845.

Kumar TP, Palakshappa MG. 2009 - Evaluation of suitable substrates for on farm production of antagonist Trichoderma harzianum. Karnataka Journal of Agricultural Sciences 22(1), 115117.

Leandro LFS, Guzman T, Ferguson LM, Fernandez GE, Louws FJ. 2007 - Population dynamics of Trichoderma in fumigated and compost-amended soil and on strawberry roots. Applied Soil Ecology 35(1), 237-246.

Lewis JA, Papavizas GC. 1984 - Chlamydospore formation by Trichoderma spp. in natural substrates. Canadian Journal of Microbiology 30(1), 1-7.

Mandal M, Paul S, Uddin MR, Mondal MA et al. 2016 - In vitro antibacterial potential of Hydrocotyle javanica Thunb. Asian Pacific Journal of Tropical Disease 6, 54-62. 
Marra R, Lombardi N, d'Errico G, Troisi J et al. 2017 - Application of Trichoderma strains and metabolites enhances soybean productivity and nutrient content. Journal of Agricultural and Food Chemistry 67(7), 1814-1822.

Muter O, Grantina-Ievina L, Makarenkova G, Vecstaudza D et al. 2017 - Effect of biochar and Trichoderma application on fungal diversity and growth of Zea mays in a sandy loam soil. Environmental and Experimental Biology 15, 289-296.

Nosir WS. 2016 - Trichoderma harzianum as a growth promoter and bio-control agent against Fusarium oxysporum f. sp. tuberosi. Advances in Crop Science and Technology 4, 217-224.

Pandya U, Saraf M. 2010 - Application of fungi as a biocontrol agent and their biofertilizer potential in agriculture. Advanced Research and Development 1, 90-99.

Rini CR, Sulochana KK. 2006 - Management of seedling rot of chilli (Capsicum annuum L.) using Trichoderma spp. and fluorescent pseudomonads (Pseudomonas fluorescens). Journal of Tropical Agriculture 44, 79-82.

Sala A, Barrena R, Artola A, Sánchez A. 2019 - Current developments in the production of fungal biological control agents by solid-state fermentation using organic solid waste. Critical Reviews in Environmental Science and Technology 49(8), 655-694.

Sangle UR, Bambawale OM. 2004 - New strains of Trichoderma spp. strongly antagonistic against Fusarium oxysporum f. sp. sesami. Journal of Mycology and Plant Pathology 34, 107-109.

Siddiquee S, Shafawati SN, Naher L. 2017 - Effective composting of empty fruit bunches using potential Trichoderma strains. Biotechnology Reports 13, 1-7.

Stewart A, Hill R. 2014 - Applications of Trichoderma in plant growth promotion. In: Gupta VK, Schmoll M, Herrera-Estrella A, Upadhyay RS, Druzhinina Irina, Tuohy MG (eds), Biotechnology and biology of Trichoderma. Elsevier, pp. 415-428.

Tewari L, Bhanu C. 2004 - Evaluation of agro-industrial wastes for conidia based inoculum production of bio-control agent: Trichoderma harzianum. Journal of Scientific and Industrial Research 63, 807-812.

Vinale F, Sivasithamparam K, Ghisalberti EL, Woo SL et al. 2014 - Trichoderma secondary metabolites active on plants and fungal pathogens. The Open Mycology Journal 8(1), 127139.

Zainap H, Nur Ain Izzati MZ, Mohd Hafiz I, Mohd Termizi Y. 2018 - Screening of potential antagonistic Trichoderma species from soil against Fusarium oxysporum f. sp. lycopersici. In: Emerging Themes in Fundamental and Applied Sciences pp. 250-256. UPM Press, Malaysia. 